\title{
Fluctuations of landings and environmental conditions in the north- western Mediterranean Sea
}

\author{
Josep Lloret $^{a *}$, Jordi Lleonart ${ }^{a}$, Ignasi Solé ${ }^{b}$ and Jean-Marc Fromentin ${ }^{c}$ \\ a Institute of Marine Sciences-CSIC, Passeig Joan de Borbó sn, E-08039 Barcelona, Catalonia, Spain \\ b Polytechnical University of Catalonia, High School of Engineering, Dept of Statistics, Avgda. Diagonal 647, E- \\ 08028 Barcelona, Catalonia, Spain \\ ${ }^{c}$ IFREMER, 1 rue Jean Villar, F-34200 Sète, France \\ *lloret@icm.csic.es
}

\begin{abstract}
Most of the monthly catches and CPUE of 13 studied commercial species in the coastal waters of the north-western Mediterranean were significantly positively correlated with run-off of local rivers (Rhône and Muga) and the wind mixing index during the spawning season, with time lags of less than a year (transfer function analyses). Rhône and Ebre interannual fluctuations in run-off were synchronous and were related to the North Atlantic Oscillation (NAO), river run-offs being negatively correlated to high NAO episodes. The fluctuations of river discharges and the wind mixing index were cyclic but not related. The results showed that enhanced hydroclimatic conditions in the NW Mediterranean were favourable for the productivity of the fish and invertebrate stocks, and suggest the presence of linkage between recruitment of Mediterranean species and local (river discharges, wind conditions) and global (NAO) environmental conditions.
\end{abstract}

Keywords: Box-Jenkins models, Ebre-River, Gulf-of-Lions, Mediterranean-fisheries Muga-River, NAO-index, Wind 


\section{INTRODUCTION}

Fish stocks are known to fluctuate extensively over a large range of spatial and temporal scales (Cushing, 1982; Laevastu, 1993). Several biotic and abiotic processes, as well as their interactions, may induce such fluctuations. At the beginning of the century, Hjort (1914; 1926) suggested that fluctuations in stock size depend upon variations in year-class strength, which are determined at an early stage through various processes (mainly food availability and environmental conditions for eggs, larvae and juveniles). Beside larval starvation, other biological factors, such as predation, competition and cannibalism may also influence the early survival of marine fish (Bailey and Houde, 1989; Fortier and Villeneuve, 1996; Myers and Cadigan, 1993). Environmental changes, such as variations in temperature, salinity, wind field and currents, can affect both the productivity and the distribution of fish stocks (e.g. Alheit and Hagen, 1997; Cushing and Dickson, 1976; Dickson and Brander, 1993; Lehodey et al., 1997; Southward et al., 1988). Finally, human exploitation has been extensively documented to influence fish dynamics and abundance, mainly through overfishing (e.g. Cook et al., 1997; Hutchings, 2000; Jennings et al., 1998).

In a previous study, Ravier and Fromentin (2001) showed that fluctuations in trap catches of Mediterranean and Atlantic bluefin tuna (Thunnus thynnus, BFT) may be decomposed into pseudo-periodic fluctuations of 100-120 years and secondarily of 20 years, which accounted for more than $50 \%$ of the total variance. Long-term fluctuations in catches were further synchronous between distant traps, so that they were likely to reflect fluctuations in BFT population migrating yearly in the Mediterranean. However, the causes of such fluctuations remained unclear. The aim of this work is to test whether the BFT long-term fluctuations might be related to large-scale environmental changes, using climate indices being available over a long period. We finally retained two 
climate indices, the North Atlantic Oscillation index (NAO, Hurrell et al., 2001; Rogers, 1984) and the Length Of the Day index (LOD, McCarthy and Badcoc, 1986), as well as the temperature for the following reasons:

- Several studies have documented the impact of the NAO on the North Atlantic food web (e.g. Fromentin and Planque, 1996) as well as its influence on the reproduction, growth and spatial distribution of fish, such as herring, cod and albacore (Alheit and Hagen, 1997; Bard, 2001; Ottersen et al., 2001). For all these reasons, the NAO could affect directly and indirectly the spatial and temporal dynamics of Atlantic BFT population (Marsac, 1999).

- Klyashtorin (1998) put forward that trends in catch of small pelagic fish on which BFT feeds (Mather et al., 1995) were closely related to the Atmospheric Climatic Index (ACI, Girs, 1974). ACI is tightly correlated with a global geophysical index, the excess Length Of the Day (LOD). As this last index is available since the $17^{\text {th }}$ century, we can test possible relationships between BFT long-term fluctuations and LOD.

- Temperature influences fish life history at various stages, i.e. larval growth and mortality (Otterlei et al., 1999; Pepin, 1991), timing of food availability for early ages (Ellersten et al., 1989), growth (Brander, 1995), maturity (Tyler, 1995), timing of spawning (Hutchings and Myers, 1994) and egg viability (Flett et al., 1996). Temperature has been also shown to play a key role in spawning activity of both tropical and temperate tunas (which spawn in warm water generally $>24^{\circ} \mathrm{C}$, Fromentin and Fonteneau, 2001; Nishikawa et al., 1985; Schaefer, 2001). Temperature is also known to influence the production and distribution of plankton (e.g. McGowan et al., 1998; Beaugrand et al., 2002) and subsequently, the food resource for juvenile and adults BFT (Mather et al., 1995). Thus, changes in temperature could also affect the spatial and temporal dynamics of Atlantic BFT. 
To test these possible relationships, we investigated and compared the patterns of variability of BFT, NAO, LOD and temperature in both the time and frequency domains, using various time series analyses and statistical techniques. 


\section{MATERIALS}

The bluefin tuna trap catches

An intensive investigation through archives and historical literature allowed us to collect more than a hundred time series of catches from the ancestral Mediterranean and Atlantic trap fishery (for more details, see Ravier and Fromentin, 2001). Traps are passive and fixed gears that were used from the Middle Age in Italy and Portugal, and from the early $19^{\text {th }}$ century in Tunisia, Spain and Morocco. They were hardly modified and their numbers and locations varied slightly until the mid-20 $20^{\text {th }}$ century (RodriguezRoda, 1964; Sella, 1929). This suggests that fishing effort is likely to have little varied over several centuries. The long-term fluctuations in trap catches represented the main source of variance and were statistically synchronous all along the western Mediterranean and the Atlantic coasts of Spain and Portugal, so that they could be considered as a good proxy of variations in BFT population migrating each year into the Mediterranean to spawn (Ravier and Fromentin, 2001, Fig. 1).

Because the time series of trap catches mainly exhibited low frequencies, we based the present study on those displaying at least a period of more than 80 contiguous years without missing values and a total percentage of missing values over the whole time series $<10 \%$, i.e. a pool of 9 time series (see Table 1 ). The longest time series came from the Sicilian traps "Favignana”, "Formica” and "Bonagia” and spread over 4 centuries $\left(17^{\text {th }}\right.$ to $\left.20^{\text {th }}\right)$, but included gaps (Table 1 , Figure 2). Records of trap catches from Sardinia (“Saline”, “Porto Paglia”, "Porto Scuso”, “Isola Piana”, Table 1, Figure 2) and Tunisia ("Sidi Daoud”) went back to the $19^{\text {th }}$ century (1825 and 1863 respectively) and those from Portugal ("Medo das Casas”) started at the beginning of the $19^{\text {th }}$ century and then spread from 1852 to 1933 (Table 1, Figure 2). 


\section{The environmental time series}

Environmental data (NAO index, LOD variations and temperatures) were collected from scientific literature, online databases or communicated by climatologists working in research institutes (Table 2). Regular and reliable climate observations, allowing the calculation of climate indices, started about 150 years ago. Such field records were primarily used when available. To follow environmental changes before the instrumental period, we used reconstructed series.

The North Atlantic Oscillation (NAO) is one of major multiannual climate fluctuations of the Northern Hemisphere (Hurrell et al., 2001; Rogers, 1984). It governs the pattern and strength of wind, temperature and precipitation over the North Atlantic, Northeast American and western European coasts (Hurrell, 1995). The NAO results from the oscillation between the subtropical high surface pressure, centred on the Azores, and the subpolar low surface pressures, centred on Iceland. To gain a satisfactory representation of what might be the fluctuations of the NAO over a long period, 3 time series were retained. The first one is the classical NAO index calculated by the difference in normalised sea level pressures between Ponta Delgadas (Azores) and Akureyri (Iceland) over the winter season (December to February, when the NAO is most pronounced, Hurrell, 1995; Rogers, 1984, Figure 3). The other indices are two NAO proxies: (i) a reconstruction based on tree-ring chronologies of North America and Europe which spreads from 1701 to 1980 (Cook et al., 1998, Figure 3) and (ii) a proxy reconstructed over the past 350 years from Greenland Ice Cores (Appenzeller et al., 1998, Figure 3). These two proxies explain $58 \%$ and $30 \%$ of the variance of the instrumental NAO index over the 1865-1980 period, respectively.

The excess Length Of the Day (LOD) is a global geophysical index, which characterises variations in the earth rotation velocity. The rotational speed of the Earth 
is subject to secular and periodic fluctuations as well as irregular or random variations. These variations have been shown to be tightly correlated with the dynamics of the Atmospheric Circulation Index (ACI) or the 'Vangengeim-Girs' Index (Girs, 1974), which characterises a dominant direction of air mass transport within Atlantic-Eurasian region. Global climate changes, such as variations in atmospheric circulation and wind stress, would affect the LOD (Klyashtorin, 1998). The LOD index is measured as the difference between the actual (astronomical) length of the day and the standard day of 86400 SI seconds (Stephenson and Morrison, 1984). The longest available LOD time series covers more than 350 years (McCarthy and Badcoc, 1986, Figure 3), but the time series appears inconsistent (data prior to 1800 displayed little variation in comparison to the 1800-1984 period, Figure 3). The International Time Bureau in Paris carries out continuous registration of the LOD since 1800. These records corroborate the above LOD index over the $1800-1984$ period.

Air temperature has been recorded in Europe since centuries and has been therefore widely used to assess environmental changes on animal populations over a long-term period (e.g. Gian-Reto et al., 2002). There is, however, no consistent time series of sea surface temperature (SST) for the Mediterranean before the most recent period. Some studies, however, showed that air temperature correlates quite well with inshore sea temperature, so that we used air temperature as a proxy of SST (e.g. Fromentin and Planque, 1996; Fromentin et al., 1998; Southward et al., 1988; Beaugrand et al., 2002). We firstly focused on two time series of temperature of the Northern Hemisphere (NH), because they were the longest ones available: (i) the annual average of the $\mathrm{NH}$ air temperature estimated over the past 150 years from a grid box of time series of land and ocean surface air temperature (Jones et al., 1997; 1999; 2001; Parker et al., 1994, Figure 3) and (ii) an annual time series of NH temperature 
reconstructed from 20 records of tree-ring width from North America, Scandinavia, Siberia and Mongolia over the past three centuries (D'Arrigo et al., 1999, Figure 3). The latter index is only based on continental data, so that it is likely to be a poorer descriptor of changes in temperature over the North Atlantic than the previous one. However, it allows the early period of the trap catches to be covered. Secondly, we investigated the possible relationships between temperature and trap catches at a regional scale, but over a shorter time period, using four instrumental temperature time series recorded at stations near to the traps (Fig. 1), i.e. Palermo in Sicily (Brunetti et al., 2000), Cagliari in Sardinia (Brunetti et al., 2000), Cadix, at the Straight of Gibraltar (Wheeler, Sunderland Polytechnic, United Kingdom, pers.com.), Dar-El-Beida in Algeria (Global Historical Climatology Network data base). 


\section{METHODS}

The total annual trap catches are given in number of tuna and were logtransformed (natural logarithm) to stabilise the variance (Sen and Srivastava, 1990). To test for relationships between BFT and environmental data, we first computed spectral analyses to compare patterns of variability in the frequency domain. Spectral analysis transforms each time series into a sum of sine and cosine functions of different period lengths (Wei, 1990). The raw periodogram is the usual way to summarise this decomposition and we calculated it using the fast Fourier transform algorithm (Matlab 6.5, 2002). However, it is a poor statistical descriptor of the spectral density since it has a large variance and it is not consistent (Bjørnstad et al., 1996; Priestley, 1981). We therefore used a Parzen smoothing window (Priestley, 1981) and compared the smoothed spectra. Spectral analysis can only be applied on continuous time series (i.e., without missing values) displaying constant intervals. All the time series have constant annual intervals, but 5 BFT time series (i.e., Medo das Casas, Favignana, Formica, Bonagia and Saline) are impaired with large gaps (see Figure 2). For these series, we applied spectral analysis over the longest continuous period (being at least 80 years long, Tables 1). Spectral analysis also assumes stationary (time independence of the mean and variance of the series, Priestley, 1981). Most of the series used in this study were stationary, but 5 of them presented a general upward trend (e.g. Cadix temperature time series). Approximate stationarity is commonly obtained by the first order difference, but this procedure suppresses medium to long-term variations. As we focused on long-term variations, we decided to perform spectral analyses on raw data, although this procedure was not totally consistent from a statistical viewpoint for these 5 time series. However, our purpose is simply descriptive and not inferential. 
Relationships between the environmental variables and BFT catches were then investigated in time domain through regression and correlation. Linear regressions were performed on each pair of BFT/environmental time series that overlapped on a sufficiently long period (i.e., 80 years minimum). To summarise the results of the regressions, we could not perform a meta-analysis (e.g. Myers et al., 2001), because of the non-independence between analyses (i.e., various BFT time series being regressed against a same climate time series). Therefore, we simply plotted the p-values of the regressions using the boxplots (S-Plus, 1999), so that we could get an indication of the distribution of the probabilities. To deal with serial correlation due to long-term fluctuations, we also fitted linear models using the generalised least squares (GLS, SPlus, 1999; Venables and Ripley, 1999). GLS model is a regression in which errors are allowed to be correlated and/or have unequal variance. Here, errors were specified to follow an autoregressive process of degree $p$, that was determined using the partial autocorrelation function and the goodness of fit of an ARIMA model (Box and Jenkins, 1976; S-Plus, 1999).

Performing linear models on each pair of BFT/environmental time series induces multiple testing, i.e. the probability of the type I error becomes larger than the nominal value $\alpha$ (e.g. Legendre and Legendre, 1998). To correct for this, we performed correlation analyses and applied the Holm's procedure for non-independent tests to compute adjusted probabilities values (which may be larger than 1, see Holm, 1979). Since some time series were not normally distributed, we used the non-parametric Spearman correlation coefficient (Zar, 1984). Correlation was tested using a Monte Carlo procedure (10,000 simulations). 


\section{RESULTS}

\section{BFT and NAO}

As already depicted by Ravier and Fromentin (2001), spectra of BFT time series were all strongly dominated by low frequencies $\left(<0.1 \mathrm{yr}^{-1}\right.$, i.e. periods $\left.>10 \mathrm{yrs}\right)$; shortto medium-term variations being weak or negligible (Fig. 4). In contrast, no common patterns emerged from the 3 NAO spectra. The instrumental Hurrell's index presented a broad band spectrum dominated by short-term variability $\left(>0.4 \mathrm{yr}^{-1}\right)$, with two smaller peaks at medium and low frequencies (around 0.3 and $0.05 \mathrm{yr}^{-1}$ ). Long-term signal emerged from the longest NAO time series. The Cook's index also displayed a broad band spectrum with a peak at low frequencies $\left(<0.1 \mathrm{yr}^{-1}\right)$ and secondarily at around 0.25 and $0.5 \mathrm{yr}^{-1}$. Appenzeller's index is dominated by low frequencies $<0.2 \mathrm{yr}^{-1}$ (i.e. periods $>5 \mathrm{yrs}$ ), with two peaks at around 0.02 and $0.15 \mathrm{yr}^{-1}$. So, in contrast with BFT spectra, medium- to short-term variability also appeared for all the three NAO indices. Pairwise regression analyses between Hurrell's index and BFT time series led to nonsignificant relationships, as it is showed by the boxplot of the p-values of the six regressions (Fig. 5a). The slopes were always weak (ranging from -0.01 to 0.08 , Table 3). It is worth noting that an increasing length of the series (i.e. analyses with the 2 NAO proxies) did not lead to stronger relationships (Fig. 5a): most of the regressions also appeared non-significant and the slope coefficients were low (and either positive or negative, i.e., from 0.32 to 0.07 , Table 3 ). The results of the GLS models (that took autocorrelation into account) were similar to the linear regressions and always nonsignificant at 5\% (Table 3). Correlation analysis confirmed the previous findings: $72 \%$ of the correlation coefficients were non-significant; this proportion rose to $88 \%$ when correction for multiple testing was applied. The results of all the above analyses 
indicated that long-term fluctuations in BFT time series were not statistically related to the NAO.

\section{$B F T$ and $L O D$}

The decomposition in frequency domain of the LOD time series showed a redshifted spectrum (frequencies $<0.1 \mathrm{yr}^{-1}$ ), similar to those of the BFT time series (Fig. 4). Five of the eight regressions between trap catches and LOD were significant (Table 3), but the boxplot of the p-values exhibited a rather large distribution of the probabilities (Fig. 5b). Further, the slopes were low (either positive or negative) and both positive and negative relationships appeared significant (3 and 2 respectively, Table 3). More careful inspection revealed strong structure in the residuals and periods of positive relationships (1750-1810, 1920-1960), alternating with periods of low or negative relationships (1850-1890). Fits of the GLS models all led to positive and nonsignificant regressions, indicating that long-term trends were the most common feature between trap catches and LOD. 75\% of the correlation coefficients were significant and about $60 \%$ when correction for multiple testing was applied. Thus, BFT time series and LOD showed fairly similar patterns in frequency domain, but regressions were not consistent among all the analyses and did not indicate any clear relationship.

\section{BFT time series and temperature}

Spectra of the two proxies of NH temperature were dominated by low frequencies and presented red-shifted spectra, similar to those of the BFT time series (Fig. 4). All the regressions between trap catches and $\mathrm{NH}$ temperature displayed strong negative slopes (from -2.90 to -0.17 , Table 3). All those with the Jones' proxy were significant at the 1\% level (Table 3, Fig. 5c) and exhibited normally distributed residuals. Concerning D’Arrigo's proxy, two BFT time series (i.e. Bonagia and Favignana) were not 
significantly related to it and further displayed time-dependent structure in the residuals. However, the 7 other regressions were significant at the 5\% level (Table 3 ) and displayed normally distributed residuals. The boxplot of the probabilities tended to confirm that BFT time series were, in general, significantly related to D’Arrigo's time series, but this was less obvious than with Jones' time series (Fig. 5c). Most of the fits of the GLS model led to lower slope coefficients (from -2.76 to 0.86 , Table 3 ) and to a significant drop in the strength of the relationship (only 2 of the 14 regressions remained significant, Table 3). This again shows that long-term trends were the most common feature to BFT, Jones' and D'Arrigo's time series. These findings were confirmed by the highly negative correlation coefficients, among which $100 \%$ (for Jones' proxy) and about 80\% (for D’Arrigo's proxy) were significant at the 5\% level for both corrected and non-corrected correlation analyses (Table 3).

The spectra of the four local temperature time series were also dominated by longterm variability, being highly similar to those of the BFT time series (Fig. 4). 23 regressions between BFT and local temperature were significant at the $1 \%$ level and the $24^{\text {th }}$ one at the $5 \%$ level (Table 3). The boxplots of the probabilities displayed unambiguous results for all the four temperature time series (Fig. 5d). All regressions exhibited downward slopes (among which 12 were particularly strong, with slope <0.5, Table 3). The GLS regressions led to lower and non-significant relationships in $86 \%$ of the cases and weak slopes coefficients (from -0.30 to 0.26 , Table 3 ). This again indicated that long-term signals were common to BFT and local temperature time series. Finally, correlation analyses confirmed the strong and negative relationships between BFT and local temperature. All the correlation coefficients were significant at $5 \%$ (and for the most at $1 \%$ ), even when correction for multiple testing was applied. 
Thus, analyses with local temperature time series corroborated those with largescale temperature proxies: (1) both BFT and the various temperature time series were largely dominated by low-frequency signals and (2) there was a clear negative relationship between the long-term fluctuations of BFT and those of temperature. 


\section{DISCUSSION}

\section{Long-term climate forcing}

Whereas NAO displayed short- to long-term variability (being different among the 3 indices), spectra of LOD, temperature and BFT time series were similar and largely dominated by low-frequency signals. Analyses in time domain did not further display any clear relationships between BFT long-term fluctuations and NAO. The results of the regression and correlation between BFT time series and LOD index were inconsistent, but they were clear and consistent between BFT time series and temperature time series: BFT long-term fluctuations appeared closely and negatively related to those in temperature.

We stressed that combining many variables may affect the level of significance of the statistical tests and, thus, the confidence in the above results. However, the Holm's procedure, which was applied to correct for multiple testing, confirmed the above findings, so that the conclusions may be considered as robust. Another difficulty relates to serial correlation in time series, which decreases the effective degrees of freedom (Bartlett, 1946). Analyses showed that regressions generally vanished when autocorrelation was taken into account, indicating that significance was due to the autocorrelated signal, i.e. the long-term fluctuations. Therefore, we may conclude that significant relationships between BFT time series and temperature time series only come from opposite long-term fluctuations, but standard statistical analyses do not allow assessment of the real level of significance of such relationships. A last methodological point relates to the fact that the analyses have been performed on different time periods (simply because the BFT time series occur over different periods and have various lengths). These differences should not bias the comparisons, especially if we assume stationarity (which is the case for most of the series). Any statistical 
relationship between two variables should indeed not depend on the time periods on which it is calculated, otherwise this would mean that the relationship is not reliable and/or the time series are not consistent. However, we recomputed the analyses on a common window greater than 80 years, i.e., 1868-1960, considering seven BFT time series (Bonagia and Medo das Casas being removed since they were never synchronous over such a period with the other BFT time series). The results computed on the common period are highly similar to those computed on different periods, so that the overall conclusion, i.e., the relationship with temperature, holds (see Figure 6).

Recent studies put forward that the NAO could affect Atlantic bluefin tuna, through its impact on recruitment (Marsac, 1999; Santiago, 1998). However, Fromentin (2002a) and the recent ICCAT workshop on environment and tuna recruitment (ICCAT, 2002) investigated the NAO/recruitment relationship, using further statistical analyses, and found no clear connection between BFT recruitment and NAO. Our results, based on long-term comparisons, support these last findings. The time delay between NAO and the recruitment period can be a critical question, especially when analyses focus on year-to-year fluctuations and are computed on short time series (which is, however, not the case in the present study). We, thus, investigated delayed effects between Hurrell's NAO index and BFT time series, using a lag from 1 to 5 years (4 to 5 years corresponding to the age-at-maturity for the East Atlantic BFT). These analyses (results not shown) did not yield to significant relationships with the three NAO indices, so that we may reject, from a statistical viewpoint, a possible connection between long-term fluctuations of the BFT and NAO.

Klyashtorin (1998) put forward that the atmospheric circulation index (ACI), that is tightly related to the excess Length Of the Day (LOD), was closely correlated with catches of the main Atlantic and Pacific commercial pelagic fish. This study focused on 
catch data that only cover the $20^{\text {th }}$ century (from 1920 or 1950 up to now). When considering the 1920-1960 period, BFT trap catches also appeared correlated to the LOD. However, the correlation vanished over the 1850-1890 period. Thus, when the long-term is considered, we do not find a relationship between BFT fluctuations and the LOD/ACI.

A potential long-term forcing of the temperature was finally investigated through six different time series of temperature. The Jones's proxy and the instrumental series of temperature from Cadix and Dar-El-Beida were reliable and validated. D’Arrigo’s proxy was reconstructed from tree-rings records, so that other meteorological (e.g. rain) or climate-independent factors could blur this index (Schmutz et al., 2000), which is calculated on inland information. This could explain why results of regressions and correlations are less clear with D'Arrigo's time series than with other temperature time series. The two Italian time series (i.e. Palermo and Cagliari) could present some problems of homogeneity between the early and the later period (Maugeri, Insituto di Fisica Generale Applicata, Italy, pers.com., see also Brunetti et al., 2000). Therefore, analyses were re-computed using a regional series for Centre-Italy, which was homogeneous and validated (Brunetti et al., 2000). The results (not shown) led to the same conclusions: BFT trap catches appeared closely and negatively related to temperature. The analyses both in time and frequency domain between BFT and temperature time series lead thus to consistent and trustworthy results. Significant regression or correlation analyses do not imply causal relationship, but neither we can deny the possibility that BFT long-term fluctuations were induced by changes in temperature. To check for it, further modelling and experimental studies are needed. However, we may discuss, on the basis of our current knowledge, the most probable underlying processes of such a relationship. 


\section{Hypothetical underlying processes}

Climate-induced fluctuations in fish catches have been demonstrated for several commercial fish stocks (e.g. Cushing, 1995; Cushing and Dickson, 1976). Fluctuations in temperature have been shown to influence: (1) the catchability (i.e., the fraction of a stock which is caught by a standardized unit of fishing effort), or in other words, the probability of capture, (2) biological processes, especially recruitment and growth of fish, and (3) the spatial dynamics of migrating fish populations (e.g. Corten, 1990; 2001; Southward et al., 1988).

A trap is a passive gear that stops mature BFT migrating along the shore and guides them to a final enclosure, where fishermen finally gaff them. Local variations in environmental conditions could affect catchability, through the success of the fishing operation and/or the fish behaviour (e.g. tuna migrating more or less offshore). However, such a process is unlikely to explain simultaneous long-term fluctuations in BFT catches between distant traps (that spread over more than $2000 \mathrm{~km}$, for more details see Ravier and Fromentin, 2001).

Long-term fluctuations in BFT traps catches could be more easily explained by hypotheses (2) and (3) (see also Fromentin and Fonteneau, 2001). Temperature is known to affect fish recruitment and growth directly, through the daily development and mortality of early stages (Pepin, 1991; Ottersen and Sundby, 1995) or indirectly, e.g., through changes in food supply for fish larvae and juvenile (Cushing, 1995). Fromentin (2002b) further showed, through simulation modelling, that stochastic variations in recruitment can lead to long-term fluctuations in the spawning stock biomass (SSB), due to the sum of the time delayed noise terms (this process being close to that known as resonant effects, see Bjørnstad et al., 1999). Thus, both long-term and short-term variations in temperature could, through their effects on recruitment and/or growth, lead 
to long-term fluctuations in BFT trap catches. The present results highlight a significant, but negative, relationship between temperature and trap catches. In other words, with warmer weather, fewer BFT were caught in the Mediterranean and Gibraltar strait. However, high temperature is expected to enhance recruitment, since the maturation and reproductive activities of tuna species (among which BFT) require temperature generally > 24 $\mathrm{C}$ (Bye, 1989; Mather et al., 1995; Schaefer, 2001; Stacey, 1989). Consequently, the relationship between temperature and BFT recruitment is expected to be positive and not negative. Therefore, we tend to dismiss the hypothesis of changes in BFT recruitment (and probably growth, but this assumption would need further information and investigation) in relation to temperature.

The negative relationship between long-term fluctuations in temperature and BFT trap catches could be more easily explained by changes in migration patterns. Changes in environmental conditions are also known to influence spatial and temporal distribution and/or migration patterns of fish (e.g. Brill and Lutcavage, 2001; Dickson and Brander, 1993; Lehodey et al., 1997; Southward et al., 1988). BFT is a large pelagic fish, which carries out a large migration over the North Atlantic for feeding and spawning. It is caught by the trap fishery when it migrates into the Mediterranean Sea to reproduce (Mather et al., 1995; Ravier and Fromentin, 2001). Fluctuations in trap catches could, therefore, result from changes in spawning migrations attributable to modifications in oceanographic conditions.

\section{Natal homing, opportunism... or something in between?}

Atlantic BFT is generally believed to visit each year one of its two identified spawning sites: the Western Mediterranean Sea (mainly around Balearic islands and Sicily) on the one hand, and the Gulf of Mexico on the other (Mather et al., 1995). The 
above results and discussion lead to question the hypothesis of "natal homing" for BFT (Cury, 1994; Cury et al., 1998). This hypothesis postulates that the newly hatched individuals retain environmental cues, which determine their future spawning environment. In the case of BFT, natal homing is first based on the millennial observations of BFT migrations into the Mediterranean (Doumenge, 1998), but this does not imply that the size of the migrating population remained constant over centuries. The second argument for natal homing is that only two BFT spawning sites (i.e. sites where both fully ripe individuals with hydrated oocytes and eggs are found) have been identified. However, Mather et al., (1995) underlined that estimating BFT spawning sites from BFT gonad conditions are subject to many limitations: (i) fully ripe BFT individuals are difficult to catch on hook as they are reluctant to feed (Sella, 1929), (ii) BFT can travel a great distance in short periods (Gunn and Block, 2001; Lutcavage et al., 2000), and (iii) BFT is a multiple spawner (Medina et al., 2002). Finally, recent archival tagging of BFT has shown a large spectrum of migration patterns (including western residency and trans-Atlantic movements, with or without annual visitation of a known spawning site) and the possibility of new breeding areas (Block et al., 1998; 2001; Gunn and Block, 2001; Lutcavage et al., 1999; 2000), a set of observations that do not support the "natal homing” hypothesis.

The alternative hypothesis to "natal homing" is that individuals track the optimal environmental conditions that will maximise their total reproductive output (Balchen, 1979; Harden Jones, 1968; Potts and Wootton, 1984). This hypothesis of “opportunistic spawning” is generally accepted for tropical tuna (Cayré, 1990). Their remarkable potential of migration allow them to explore a large range of environmental conditions and to select the most suitable ones for their physiological and biological needs. However, unlike tropical tuna, temperate tuna feed and spawn in different areas 
(Fromentin and Fonteneau, 2001; Mather et al., 1995). Opportunistic spawning is, thus, unlikely for BFT.

Finally, we suggest that BFT reproductive strategy could be in between the two above hypotheses, i.e. a kind of “opportunistic homing”. A recent physiological study pointed out that the last stages of BFT gonad maturation (intense production of yolked oocytes of stages 3 and 4) occurred within a short period of time and probably under the control of temperature (Medina et al., 2002). If suitable temperatures induce the last stages of gametogenis and thus, reproduction, one may hypothesise that more locations in the North Atlantic (encountered by BFT along their migration route) could be suitable for spawning as water temperature increases. In other words, the Atlantic BFT population could also reproduce elsewhere than in its traditional grounds (i.e., the Western Mediterranean Sea and the Gulf of Mexico) during warm periods. This hypothesis is in agreement with some pop-up tag records (Lutcavage et al., 1999) and several past works, which have mentioned the occurrence of other hypothetical spawning areas, such as the Ibero-Moroccan bay and the Bay of Biscay (e.g. Buen (de), 1927; 1935; Mather et al., 1995). During cold periods, reproductive activities would be, in contrast, restricted to the traditional and permanent spawning grounds (which would further remain suitable during warm ones). This hypothesis of an "opportunistic homing", which combines the "natal homing" hypothesis with the opportunistic reproductive strategy of tuna, is consistent with our results and current knowledge on tuna. This hypothesis could be tested by gathering new in situ information on migrations and environmental preferences of BFT, e.g. by combining pop-up archival tags with satellite oceanography and ocean modelling. 


\section{ACKNOWLEDGEMENTS}

We are grateful to C. Appenzeller, M. Brunetti, L. Buffoni, R. D’Arrigo, J. Luterbacher, M. Maugeri, T. Nanni and D. Wheeler for providing environmental time series and their helpful comments. Thanks are also due to F. Doumenge, H. Farrugio, A. Fonteneau, A. Hattour, J.M. Ortiz de Urbina, C. Piccinetti, J.M. de la Serna and the Duchess of Medina Sidonia, for providing historical trap catches data or information. Financial support from the European project STROMBOLI (EU-DGXIV 99/022), the French programme PNEC (Programme National "Environnement Côtier") and IFREMER (Ph.D. fellowship for C. Ravier) made the analyses possible. 


\section{REFERENCES}

Alheit, J. and Hagen, E. (1997) Long-term climate forcing of European herring and sardine populations. Fish. Oceanogr. 6:130-139.

Appenzeller, C., Stocker, T.F. and Anklin, M. (1998) North Atlantic Oscillation dynamics recorded in Greenland ice cores. Science 282:446-449.

Bailey, K.M. and Houde, E.D. (1989) Predation on eggs and larvae of marine fishes and the recruitment problem. Adv. Mar. Biol. 26:1-83.

Balchen, J.D. (1979) Modelling, prediction and control of fish behaviour. In: Control and dynamic systems. Leondes (ed.) Academic Press: London, Vol. 15, pp. 99-146.

Bard, F.X. (2001) Extension of the geographical and vertical habitat of albacore (Thunnus alalunga) in the North Atlantic. Possible consequences on true rate of exploitation of this stock. Col. Vol. Sci. Pap. ICCAT 52:1447-1456.

Bartlett, M.S. (1946) On the theoretical specification of sampling properties of autocorrelated time series. J. R. Stat. Soc. Suppl. 8:24-411.

Beaugrand, G.; Reid, P.C.; Ibanez, F.; Lindley, J.A.; Edwards, M. (2002) Reorganization of North Atlantic marine copepod biodiversity and climate. Science 296:1692-1694

Bjørnstad, O.N., Champely, S., Stenseth, N.C. and Saitoh, T. (1996) Cyclicity and stability of grey-sided voles, Clethrinomys rufocanus of Hokkaido: evidence from spectral and Principal components analyses. Phil. Trans. R. Soc. Lond. B 351:867-875.

Bjørnstad, O.N., Fromentin, J.-M., Stenseth, N.C. and Gjøsæter, J. (1999) Cycles and trends in cod populations. Proc. Nat. Acad. Sci. USA 96:5066-5071.

Block, B.A., Dewar, H., Farwell, C. and Prince, E.D. (1998) A new satellite technology for tracking the movements of Atlantic bluefin tuna. Proc. Nat. Acad. Sci. USA 95:9384-9389. 
Block, B.A., Dewar, H., Blackwell, S.B., Williams, T.D., Prince, E.D., Farwell, C.J., Boustany, A., Teo, S.L.H., Seitz, A., Walli, A. and Fudge, D. (2001) Migratory movements, depth preferences, and thermal biology of Atlantic bluefin tuna. Science 293:1310-1314.

Box, G.E.P. and Jenkins, G.M. (1976) Time series analysis forecasting and control. Holden-Day: San Francisco.

Brander, K.M. (1995) The effect of temperature on growth of Atlantic cod (Gadus morhua, L.). ICES J. Mar. Sci. 52:1-10.

Brill, R.W. and Lutcavage, M.E. (2001) Understanding environmental influences on movements and depth distributions of tunas and billfishes can significantly improve population assessments. American Fisheries Society Symposium 25:179-198.

Brunetti, M., Buffoni, L., Maugeri, M. and Nanni, T. (2000) Trends of minimum and maximum daily temperatures in Italy from 1865 to 1996. Theor. Appl. climatol. 66:4960.

Buen (de), F. (1927) Notes et bibliographie sur la biologie du thon. Rapp. P.-v Réun. Cons. int. Explor. mer 44:98-107.

Buen (de), F. (1935) Aires de ponte du thon (Thunnus thynnus (L.)). In: XII Congrès International de Zoologie Lisbonne, Vol. 3(11-12), pp. 2133-2136.

Bye, V.J. (1989) The role of environmental factors in the timing of reproductive cycles. In: Fish reproduction: Strategies and tactics. Potts, G.W. and Wooton, R.J. (eds) Academic press: London, pp. 187-205.

Cayré, P. (1990) Les migrations : un comportement déclenché et guidé par l'environnement. Col. Vol. Sci. Pap. ICCAT 32:158-168. 
Cook, E.R., D'Arrigo, R. and Briffa, K.R. (1998) A reconstruction of the North Atlantic Oscillation using tree-ring chronologies from the North America and Europe. Holocene 8:9-17.

Cook, R.M., Sinclair, A. and Stefansson, G. (1997) Potential collapse of the North Sea cod stocks. Nature 385:521-522.

Corten, A. (1990) Long-term trends in pelagic fish stocks of the North Sea and adjacent waters and their possible connection to hydrographic changes. Neth. J. Sea Res. 25:227235.

Corten, A. (2001) Northern distribution of the North Sea herring as a response to high water temperatures and/or low food abundance. Fish. Res. 50:189-204.

Cury, P. (1994) Obstinate nature: An ecology of individuals. Thoughts on reproductive behaviour and biodiversity. Can. J. Fish. Aquat. Sci. 51:1664-1673.

Cury, P., Anneville, A., Bard, F.X., Fonteneau, A. and Roy, C. (1998) Obstinate North Atlantic bluefin tuna (Thunnus thynnus thynnus): an evolutionary perspective to consider spawning migration. Col. Vol. Sci. Pap. ICCAT 50:239-247.

Cushing, D.H. (1982) Climate and fisheries. Academic Press: London.

Cushing, D.H. (1995) Population production and regulation in the sea. A fishery perspective. Cambridge University Press: Cambridge.

Cushing, D.H. and Dickson, R.R. (1976) The biological response in the sea to climatic changes. Adv. Mar. Biol. 14:1-122.

D'Arrigo, R., Jacoby, G., Free, M. and Robock, A. (1999) Northern hemisphere temperature variability for the past three centuries: tree-ring and model estimates. Clim. Change 42:663-675.

Dickson, R.R. and Brander, K.M. (1993) Effects of a changing windfield on cod stocks of the North Atlantic. Fish. Oceanogr. 2:124-153. 
Doumenge, F. (1998) L'histoire des pêches thonières. Col. Vol. Sci. Pap. ICCAT 50:753-802.

Ellersten, B., Fossum, P., Solemdal, P. and Sundby, S. (1989) Relation between temperature and survival of eggs and firstfeeding larvae of northeast Arctic cod (Gadus morhua L.). Rapp. P.-v. Réun. Cons. int. Explor. Mer 191:209-219.

Flett, P.A., Munkittrick, K.R., Van Der Kraar, G. and Leatherland, J.F. (1996) Overripening as the cause of low survival to hatch in Lake Erie coho salmon (Oncorhyncus kisutch) embryos. Can. J. Zool. 74:851-857.

Fortier, L. and Villeneuve, A. (1996) Cannibalism and predation of fish larvae by larvae of Atlantic mackerel, Scomber scombrus, trophodynamics and potential impact on recruitment. Fish. Bull. 94:268-281.

Fromentin, J.-M. (2002a) Is the recruitment a key biological process in the hypothetical NAO-Atlantic tunas relationships? Col. Vol. Sci. Pap. ICCAT 54:1008-1016.

Fromentin, J.-M. (2002b) Can stochastic variations in recruitment induce long-term fluctuations in the carrying capacity? Col. Vol. Sci. Pap. ICCAT 54:985-991.

Fromentin, J.-M. and Planque, B. (1996) Calanus and environment in the eastern North Atlantic. 2) Role of the North Atlantic Oscillation on Calanus finmarchicus and $C$. helgolandicus. Mar. Ecol. Prog. Ser. 134:111-118.

Fromentin, J.-M. and Fonteneau, A. (2001) Fishing effects and life history traits: a casestudy comparing tropical versus temperate tunas. Fish. Res. 53:133-150.

Fromentin, J.-M., Stenseth, N.C., Gjøsæter, J., Johannessen, T. and Planque, B. (1998) Long-term fluctuations in cod and pollack along the Norwegian Skagerrak coast. Mar. Ecol. Prog. Ser. 162:265-278. 
Gian-Reto, W., Post, E., Convey, P., Menzel, A., Parmesank, C., Beebee, T.J.C., Fromentin, J.-M., Hoegh-Guldberg, O. and Bairlein, F. (2002) Ecological responses to recent climate change. Nature 416:389-395.

Girs, A.A. (1974) Macrocirculation method for long-term meteorological prognosis. Hydrometizdat: Leningrad.

Gunn, J. and Block, B.A. (2001) Advances in acoustic, archival, and satellite tagging of tunas. In: Tuna: physiology, ecology and evolution. Block, B.A. and Stevens, E.D. (eds) Academic press: New York, pp. 167-224.

Harden Jones, F.R. (1968) Fish migration. Arnold: London.

Hjort, J. (1914) Fluctuations in the great fisheries of northern Europe. Viewed in the light of biological research. Rapp. P.-v Réun. Cons. int. Explor. mer 20:1-228.

Hjort, J. (1926) Fluctuations in the year classes of important food fishes. J. Cons. int. Explor. Mer 1:5-38.

Holm, S. (1979) A simple sequentially rejective multiple test procedure. Scand. J. Stat. 6:65-70.

Hurrell, J.W. (1995) Decadal trends in the North Atlantic Oscillation: regional temperatures and precipitations. Science 269:676-679.

Hurrell, J.W., Kushnir, Y. and Visbeck, M. (2001) The North Atlantic Oscillation. Science 291:603-604.

Hutchings, J.A. (2000) Collapse and recovery of marine fishes. Nature 406:882-885. Hutchings, J.A. and Myers, R.A. (1994) What can be learned from the collapse of a renewable resource? Atlantic cod, Gadus morhua, of Newfoundland and Labrador. Can. J. Fish. Aquat. Sci. 51:2126-2146.

ICCAT (2002) Report of the workshop on environment and tuna recruitment. Col. Vol. Sci. Pap. ICCAT 54:895-952. 
Jennings, S., Reynolds, J.D. and Mills, S.C. (1998) Life history correlates of responses to fisheries exploitation. Proc. Roy. Soc. London Ser. B 265:333-339.

Jones, P.D., Osborn, T.J. and Briffa, K.R. (1997) Estimating sampling errors in largescale temperature averages. J. Clim. 10:2548:2568.

Jones, P.D., New, M., Parker, D.E., Martin, S. and Rigor, I.G. (1999) Surface air temperature and its changes over the past 150 years. Rev. Geophys. 37:173-199.

Jones, P.D., Osborn, T.J., Briffa, K.R., Folland, C.K., Horton, E.B., Alexander, L.V., Parker, D.E. and Rayner, N.A. (2001) Adjusting for sampling density in grid box land and ocean surface temperature time series. J. Geophys. Res. Atm. 106(D4):3371:3380. Klyashtorin, L. (1998) Long-term climate change and main commercial fish production in the Atlantic and Pacific. Fish. Res. 37:115-125.

Laevastu, T. (1993) Marine climate, weather and fisheries. Blackwell Scientific Publications: Oxford.

Legendre, P. and Legendre, L. (1998) Numerical Ecology. Elsevier: Amsterdam.

Lehodey, P., Bertignac, M., Hampton, J., Lewis, A. and Picaut, J. (1997) El Nino Southern Oscillation and tuna in the western Pacific. Nature 389:715-718.

Lutcavage, M.E., Brill, R.W., Skomal, G.B., Chase, B.C. and Howey, P.W. (1999) Results of pop-up satellite tagging of spawning size class fish in the Gulf of Maine: do North Atlantic bluefin tuna spawn in the mid-Atlantic ? Can. J. Fish. Aquat. Sci. 56:173-177.

Lutcavage, M.E., Brill, R.W., Skomal, G.B., Chase, B.C., Goldstein, J.L. and Tutein, J. (2000) Tracking adult North Atlantic bluefin tuna (Thunnus thynnus) in the northwestern Atlantic using ultrasonic telemetry. Mar. Biol. 137:347:358. 
Marsac, F. (1999) Changements hydroclimatiques observés dans l'Atlantique depuis les années 50 et impacts possibles sur quelques stocks de thons et leur exploitation. Col. Vol. Sci. Pap. ICCAT 49:346-370.

Mather, F.J., Mason, J.M. and Jones, A.C. (1995) Historical Document: Life History and Fisheries of Atlantic Bluefin Tuna. NOAA Technical Memorandum, NMFS-SEFSC - 370.

Matlab 6.5 (2002) Using Matlab - Data analysis and statistics. The Mathworks Inc. Natick, Massachusetts

McCarthy, D. and Badcoc, A. (1986) The length of the day since 1656. Phys. Earth Planet. Inter. 44:281-292.

McGowan, J.A., Cayan, D.R. and Dorman, L.M. (1998) Climate-ocean variability and ecosystem response in the Northeast Pacific. Science 281:210-217.

Medina, A., Abascal, F.J., Megina, C. and Garcia, A. (2002) Stereological assessment of the reproductive status of female Atlantic northern bluefin tuna during migration to Mediterranean spawning ground through the Strait of Gibraltar. J. Fish. Biol. 60:203:217.

Myers, R.A. and Cadigan, N.G. (1993) Density-dependant juvenile mortality in marine demersal fish. Can. J. Fish. Aquat. Sci. 50:1576-1590.

Myers, R.A., MacKenzie, B.R., Bowen, K.G. and Barrowman, N.J. (2001) What is the carrying capacity for fish in the ocean? A meta-analysis of population dynamics North Atlantic cod. Can. J. Fish. Aquat. Sci. 58:1464-1476.

Nishikawa, Y., Honma, M., Ueyanagi, S. and Kikawa, S. (1985) Average distribution of larvae of oceanic species of scombroid species, 1956 - 1981. Bull. Far Sea Fish. Lab. S. Series 12:99 pp. 
Otterlei, E., Nyhammer, G., Folkvord, A. and Stefansson, S.O. (1999) Temperature- and size-dependant growth of larval and early juvenile Atlantic cod (Gadus morhua): a comparative study of Norwegian coastal cod and northeast Arctic cod. Can. J. Fish. Aquat. Sci. 56:2099-2111.

Ottersen, G. and Sundby, S. (1995) Effects of temperature, wind and spawning stock biomass on recruitment of Arcto-Norwegian cod. Fish. Oceanogr. 4:278-292.

Ottersen, G., Planque, B., Belgrano, A., Post, E., Reid, P.C. and Stenseth, N.C. (2001) Ecological effects of the North Atlantic Oscillation. Oecologia 128:1-14.

Parker, D.E., Jones, P.D., Bevan, A. and Folland, C.K. (1994) Interdecadal changes of surface temperature since the late 19th century. J. Geophys. Res. 99:14373-14399.

Pepin, P. (1991) Effect of temperature and size on development, mortality and survival rates of the pelagic early life history stages of marine fish. Can. J. Fish. Aquat. Sci. 48:503-518.

Potts, G.W. and Wootton, R.J. (1984) Fish reproduction: strategies and tactics. Academic Press: London.

Priestley, M.B. (1981) Spectral analysis and times series. Academic Press: London. Ravier, C. and Fromentin, J.-M. (2001) Long-term fluctuations in the Eastern Atlantic and Mediterranean bluefin tuna population. ICES J. mar. Sci. 58:1299-1317. Rodriguez-Roda, J. (1964) Biologia del Atun, Thunnus thynnus (L.), de la costa sudatlantica de Espana. Investigacion Pesquera 25:33-146.

Rogers, J.C. (1984) The association between the North Atlantic Oscillation and the Southern Oscillation in the Northern Hemisphere. Mon. Wea. Rev. 112:1999-2015.

Santiago, J. (1998) The North Atlantic Oscillation and recruitment of temperate tunas. Col. Vol. Sci. Pap. ICCAT 48:240-249. 
Schaefer, K.M. (2001) Reproductive biology of tunas. In: Tuna: physiology, ecology and evolution. Block, B.A. and Stevens, E.D. (eds) Academic press: New York, pp. 225-270.

Schmutz, C., Luterbacher, J., Gyalistras, D., Xoplaki, E. and Wanner, H. (2000) Can we trust proxy-based NAO index reconstructions ? Geophys. Res. Lett. 27:1135-1138.

Sella, M. (1929) Migrazioni e habitat del tonno (Thunnus thynnus, L.) studiati col metodo degli ami, con osservazioni su l'accrescimento, sul regime delle tonnare ecc. Memoria, R. Comitato Talassografico Italiano 156:511-542.

Sen, A. and Srivastava, M. (1990) Regression analysis: theory, methods and applications. Springer-Verlag: New-York.

Southward, A.J., Boalch, G.T. and Maddock, L. (1988) Fluctuations in the herring and pilchard fisheries of Devon and Cornwall linked to change in climate since the 16th century. J. Mar. Biol. Ass. U.K. 68:423-445.

S-Plus (1999) S-plus 2000 Guide to statistics, Vol. 1 and Vol. 2. MathSoft, Inc.: Seattle, Washington.

Stacey, N.E. (1989) Control of the timing of ovulation by exogenous and endogenous factors. In: Fish reproduction: Strategies and tactics. Potts, G.W. and Wooton, R.J. (eds) Academic press: London, pp. 207-222.

Stephenson, F.R. and Morrison, L.V. (1984) Long-term changes in the rotation of the Earth: 700BC to AD 1980. Phil. Trans.R. Soc. Lond. A 313:47-70.

Tyler, A.V. (1995) Warm-water and cool-water stocks of Pacific cod (Gadus macrocephalus): a comparative study of reproductive biology and stock dynamics. Climate change and northern fish populations. Can. Spec. Publ. Fish. Aquat. Sci. 121:537-545. 
Venables, W.N. and Ripley, B.D. (1999) Modern applied statistics with S-Plus; 3rd edition. Springer-Verlag: New-York.

Wei, W.W.S. (1990) Times series analysis. Univariate and multivariate methods. Addison Wesley: Redwood City, California.

Zar, J.H. (1984) Biostatistical analysis. 2nd ed. Prentice-Hall: New Jersey. 


\section{LEGENDS}

Figure 1. Map of the western Mediterranean and adjacent North Atlantic. Arrows indicate spawning migration routes of bluefin tuna and grey areas the known spawning sites in the Mediterranean Sea (from Mather et al., 1995). Numbers denote the locations of the traps: (1) Medo das Casas, (2) Sidi Daoud, (3-5) Favignana, Formica and Bonagia (6) Saline, (7-9) Porto Paglia, Porto Scuso and Isola Piana. $T$ denotes the locations of the stations of instrumental temperature (from the left to the right): Cadix, Dar-ElBeida, Cagliari and Palermo.

Figure 2. Plots of the 9 BFT time series (thin line: log data; bold line: running median of order 3). $\mathrm{N}$ is catch (BFT/year)

Figure 3. Plots of the 10 environmental time series (thin line: log data; bold line: running median of order 3).

Figure 4. Left panel: smoothed periodograms of the 9 BFT time series, right panel: smoothed periodograms of the 10 environmental time series. BFT (trap catches), LOD, and temperature time series were dominated by low frequencies, whereas the NAO time series displayed both high and low frequencies.

Figure 5. Box-plots of the p-values of the linear regressions between the BFT time series and: (a) the NAO index from Hurrell ( $\mathrm{N}=6$ regressions), Jones $(\mathrm{N}=9)$ and Appenzeller ( $\mathrm{N}=9$ ), (b) the LOD index $(\mathrm{N}=8)$, (c) the Northern Hemisphere temperatures from Jones $(\mathrm{N}=6)$ and D'Arrigo $(\mathrm{N}=9)$, (d) instrumental temperatures 
from Cadix $(\mathrm{N}=6)$, Dar-El-Beida $(\mathrm{N}=6)$, Cagliari $(\mathrm{N}=6)$, and Palermo $(\mathrm{N}=6)$; inset gives a zoom of the p-values between 0 and 0.01 . Median, first and third quartile, and 1.5 by inter-quartile range are plotted. The p-values of the regressions with NAO and LOD appeared non-significant and widely distributed between 0 and 1 , whereas those with temperature were all close to a p-value $=0$.

Figure 6. Box-plots of the p-values of the correlation analyses calculated between the BFT and environmental time series on: (a) different time periods (i.e., same as Figure 5, but for correlation) and (b) a common period (restricted to the years 1868-1960).

Table 1. Main characteristics of the trap catch time series: index, area (country or region), name, period with continuous data $\geq 80$ years, total number of observations of the time series $(\mathrm{N})$, median and coefficients of variation (C.V., as the standard deviation*100 and scaled by the mean).

Table 2. Main characteristics of the environmental time series: type of variable, source (instrumental or reconstructed), period and bibliographic reference.

Table 3. Results from the analyses between environmental and BFT time series: number of observations used in the regressions and correlations $(\mathrm{N})$, slope and p-value of the linear regressions and generalised least squares models (GLS) and uncorrected and Holm's corrected probabilities of the Spearman correlation coefficient. Bold values indicate significant probabilities at the $5 \%$ level. When the trap catches time series was discontinuous, GLS model was fitted on the longest period available. 
Table 1

\begin{tabular}{|cclcccc|}
\hline No. & Area & Trap name & Period & N & Median & C.V. \\
\hline 1 & Portugal & Medo das Casas & $1852-1933$ & 112 & 8.90 & $10.57 \%$ \\
2 & Tunisia & Sidi Daoud & $1863-1960$ & 98 & 8.36 & $10.09 \%$ \\
3 & Sicily & Formica & $1634-1813$ & 302 & 7.58 & $9.02 \%$ \\
& & & $1878-1960$ & & & \\
4 & Sicily & Favignana & $1634-1813$ & 302 & 7.56 & $10.74 \%$ \\
& & & $1878-1960$ & & & \\
5 & Sicily & Bonagia & $1657-1809$ & 249 & 6.82 & $10.73 \%$ \\
6 & Sardinia & Saline & $1868-1960$ & 114 & 7.50 & $12.19 \%$ \\
7 & Sardinia & Porto Paglia & $1825-1960$ & 138 & 7.37 & $10.31 \%$ \\
8 & Sardinia & Porto Scuso & $1825-1960$ & 139 & 7.95 & $8.85 \%$ \\
9 & Sardinia & Isola Piana & $1825-1960$ & 139 & 7.73 & $9.16 \%$ \\
\hline
\end{tabular}


Table 2

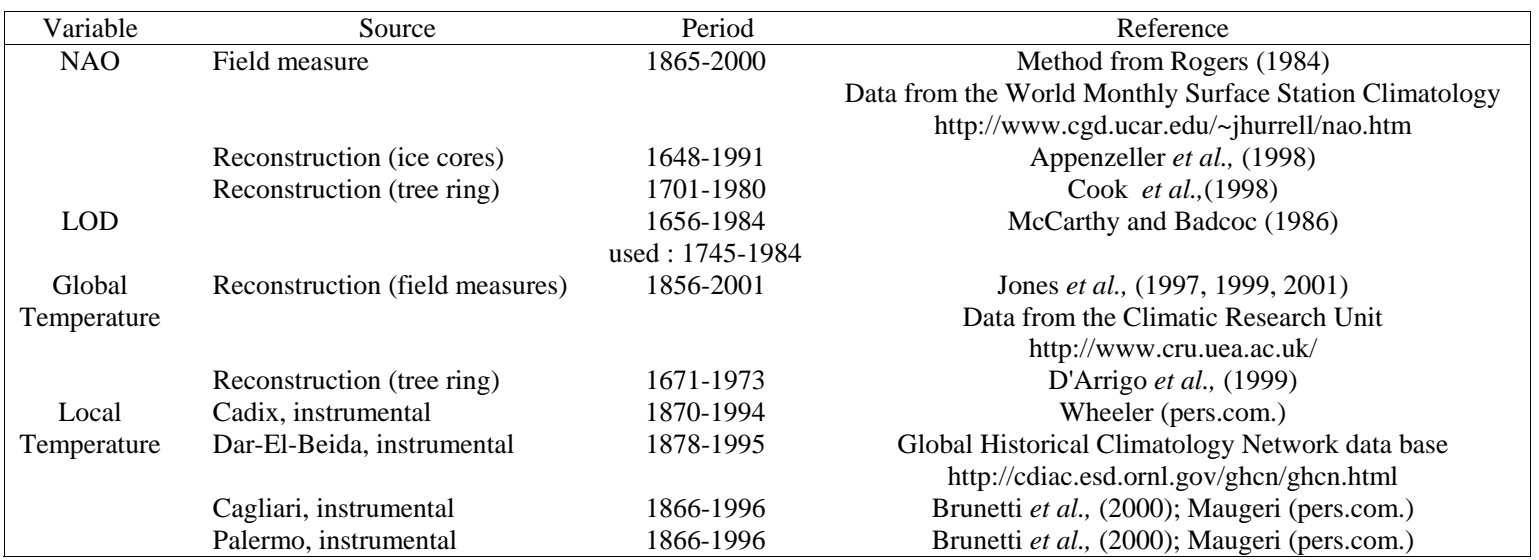


Table 3

\begin{tabular}{|c|c|c|c|c|c|c|c|c|}
\hline \multirow[t]{2}{*}{$\begin{array}{l}\text { Environmental } \\
\text { time-series }\end{array}$} & \multirow[t]{2}{*}{ Trap } & \multirow[t]{2}{*}{$\mathrm{N}$} & \multicolumn{2}{|c|}{ Linear regression } & \multicolumn{2}{|c|}{$\begin{array}{l}\text { Generalised Least } \\
\text { Squares model }\end{array}$} & \multicolumn{2}{|c|}{ Correlation } \\
\hline & & & slope & p-value & slope & p-value & p-value & p-value \\
\hline \multirow{6}{*}{ Hurrell NAO } & Sidi Daoud & 96 & 0.08 & 0.1190 & 0.05 & 0.0639 & 0.0604 & 0.3020 \\
\hline & Formica & 83 & 0.08 & 0.0690 & 0.06 & 0.0655 & 0.0200 & 0.1200 \\
\hline & Favignana & 83 & 0.05 & 0.3087 & 0.02 & 0.4403 & 0.1300 & 0.4244 \\
\hline & Saline & 93 & -0.01 & 0.9095 & -0.03 & 0.3907 & 0.4776 & 0.4840 \\
\hline & Porto Scuso & 96 & 0.04 & 0.3133 & 0.04 & 0.2214 & 0.1061 & 0.4244 \\
\hline & Isola Piana & 96 & 0.02 & 0.6749 & 0.00 & 0.8909 & 0.2420 & 0.4840 \\
\hline \multirow[t]{9}{*}{ Cook NAO } & Medo das Casas & 112 & -0.05 & 0.0044 & 0.00 & 0.9307 & 0.0005 & 0.0045 \\
\hline & Sidi Daoud & 98 & -0.02 & 0.3135 & 0.01 & 0.1775 & 0.0494 & 0.2470 \\
\hline & Formica & 217 & 0.00 & 0.8653 & 0.00 & 0.9892 & 0.2975 & 0.7976 \\
\hline & Favignana & 214 & 0.00 & 0.9060 & 0.02 & 0.0224 & 0.4350 & 0.7976 \\
\hline & Bonagia & 179 & 0.00 & 0.7231 & -0.02 & 0.0598 & 0.2591 & 0.7976 \\
\hline & Saline & 114 & -0.04 & 0.0450 & -0.01 & 0.4863 & 0.0050 & 0.0400 \\
\hline & Porto Paglia & 136 & 0.00 & 0.8230 & 0.02 & 0.0448 & 0.1994 & 0.7976 \\
\hline & Porto Scuso & 136 & -0.02 & 0.0619 & 0.01 & 0.5681 & 0.0326 & 0.2258 \\
\hline & Isola Piana & 136 & -0.02 & 0.0724 & 0.00 & 0.8425 & 0.0386 & 0.2316 \\
\hline Appenzeler & Medo das Casas & 112 & -0.32 & 0.0000 & -0.02 & 0.7832 & 0.0008 & 0.0072 \\
\hline NAO & Sidi Daoud & 98 & -0.08 & 0.2971 & 0.02 & 0.7746 & 0.3876 & 1.2548 \\
\hline & Formica & 270 & 0.01 & 0.8371 & -0.02 & 0.6659 & 0.4384 & 1.2548 \\
\hline & Favignana & 267 & -0.09 & 0.0647 & -0.09 & 0.0451 & 0.0907 & 0.7016 \\
\hline & Bonagia & 227 & 0.07 & 0.1293 & 0.01 & 0.8967 & 0.1509 & 0.9054 \\
\hline & Saline & 114 & -0.06 & 0.4696 & 0.02 & 0.7190 & 0.3804 & 1.2548 \\
\hline & Porto Paglia & 136 & -0.11 & 0.0671 & 0.00 & 0.9855 & 0.0877 & 0.7016 \\
\hline & Porto Scuso & 136 & -0.05 & 0.3346 & 0.02 & 0.6934 & 0.1616 & 0.9054 \\
\hline & Isola Piana & 136 & -0.05 & 0.3544 & -0.01 & 0.8650 & 0.3137 & 1.2548 \\
\hline LOD & Medo das Casas & 112 & -0.15 & 0.0027 & 0.09 & 0.2404 & 0.0000 & 0.0000 \\
\hline & Sidi Daoud & 98 & -0.09 & 0.0687 & 0.06 & 0.4814 & 0.0041 & 0.0205 \\
\hline & Formica & 198 & 0.13 & 0.0008 & 0.07 & 0.4471 & 0.0123 & 0.0492 \\
\hline & Favignana & 195 & 0.28 & 0.0000 & 0.02 & 0.8045 & 0.0001 & 0.0006 \\
\hline & Saline & 114 & -0.04 & 0.4291 & 0.20 & 0.0582 & 0.0418 & 0.1254 \\
\hline & Porto Paglia & 136 & -0.16 & 0.0000 & 0.01 & 0.9331 & 0.0000 & 0.0000 \\
\hline & Porto Scuso & 136 & 0.01 & 0.8111 & 0.14 & 0.0502 & 0.3354 & 0.3354 \\
\hline & Isola Piana & 136 & 0.09 & 0.0148 & 0.14 & 0.0541 & 0.0880 & 0.1760 \\
\hline Jones & Sidi Daoud & 98 & -2.20 & 0.0000 & -0.45 & 0.2215 & 0.0000 & 0.0000 \\
\hline Temperature & Formica & 83 & -1.71 & 0.0000 & -0.66 & 0.1415 & 0.0000 & 0.0000 \\
\hline & Favignana & 83 & -2.06 & 0.0000 & -0.56 & 0.1287 & 0.0000 & 0.0000 \\
\hline & Saline & 93 & -2.18 & 0.0000 & 0.44 & 0.2999 & 0.0000 & 0.0000 \\
\hline & Porto Scuso & 105 & -1.46 & 0.0000 & -0.28 & 0.4386 & 0.0000 & 0.0000 \\
\hline & Isola Piana & 105 & -1.41 & 0.0000 & -0.15 & 0.6220 & 0.0000 & 0.0000 \\
\hline D’Arrigo & Medo das Casas & 112 & -1.72 & 0.0028 & -0.75 & 0.4874 & 0.0000 & 0.0000 \\
\hline Temperature & Sidi Daoud & 98 & -2.90 & 0.0000 & -2.75 & $<.0001$ & 0.0000 & 0.0000 \\
\hline & Formica & 247 & -0.76 & 0.0005 & -0.07 & 0.9041 & 0.0003 & 0.0015 \\
\hline & Favignana & 244 & -0.17 & 0.5358 & 0.20 & 0.7423 & 0.2595 & 0.4930 \\
\hline & Bonagia & 209 & -0.31 & 0.2998 & 0.86 & 0.2017 & 0.2465 & 0.4930 \\
\hline & Saline & 114 & -2.31 & 0.0000 & -2.76 & $<.0001$ & 0.0000 & 0.0000 \\
\hline & Porto Paglia & 136 & -1.34 & 0.0000 & -0.79 & 0.1112 & 0.0000 & 0.0000 \\
\hline & Porto Scuso & 136 & -0.96 & 0.0000 & -0.19 & 0.7474 & 0.0003 & 0.0015 \\
\hline & Isola Piana & 136 & -0.50 & 0.0318 & -0.01 & 0.9852 & 0.0204 & 0.0612 \\
\hline Cadix & Sidi Daoud & 91 & -0.81 & 0.0000 & -0.04 & 0.7617 & 0.0000 & 0.0000 \\
\hline Temperature & Formica & 83 & -0.61 & 0.0000 & -0.30 & 0.0349 & 0.0001 & 0.0002 \\
\hline & Favignana & 83 & -0.70 & 0.0000 & -0.27 & 0.0176 & 0.0000 & 0.0000 \\
\hline & Saline & 91 & -0.94 & 0.0000 & -0.09 & 0.5804 & 0.0000 & 0.0000 \\
\hline & Porto Scuso & 91 & -0.64 & 0.0000 & -0.23 & 0.0946 & 0.0000 & 0.0000 \\
\hline & Isola Piana & 91 & -0.48 & 0.0002 & -0.13 & 0.2042 & 0.0000 & 0.0000 \\
\hline Dar-El-beida & Sidi Daoud & 83 & -0.54 & 0.0000 & -0.01 & 0.9181 & 0.0000 & 0.0000 \\
\hline Temperature & Formica & 83 & -0.49 & 0.0000 & -0.17 & 0.1219 & 0.0000 & 0.0000 \\
\hline & Favignana & 83 & -0.55 & 0.0000 & -0.14 & 0.0982 & 0.0000 & 0.0000 \\
\hline & Saline & 83 & -0.71 & 0.0000 & 0.01 & 0.9546 & 0.0000 & 0.0000 \\
\hline & Porto Scuso & 83 & -0.46 & 0.0001 & -0.08 & 0.4603 & 0.0000 & 0.0000 \\
\hline & Isola Piana & 83 & -0.44 & 0.0000 & -0.07 & 0.3893 & 0.0000 & 0.0000 \\
\hline Cagliari & Sidi Daoud & 96 & -0.44 & 0.0017 & 0.03 & 0.7314 & 0.0026 & 0.0052 \\
\hline Temperature & Formica & 83 & -0.54 & 0.0000 & -0.24 & 0.0402 & 0.0000 & 0.0000 \\
\hline & Favignana & 83 & -0.60 & 0.0000 & -0.13 & 0.1586 & 0.0000 & 0.0000 \\
\hline & Saline & 93 & -0.53 & 0.0010 & -0.01 & 0.9422 & 0.0003 & 0.0006 \\
\hline & Porto Scuso & 96 & -0.34 & 0.0059 & 0.01 & 0.9054 & 0.0041 & 0.0123 \\
\hline & Isola Piana & 96 & -0.38 & 0.0005 & 0.04 & 0.6899 & 0.0004 & 0.0016 \\
\hline Palermo & Sidi Daoud & 96 & -0.44 & 0.0007 & 0.11 & 0.2845 & 0.0003 & 0.0009 \\
\hline Temperature & Formica & 83 & -0.40 & 0.0004 & -0.16 & 0.1800 & 0.0001 & 0.0004 \\
\hline & Favignana & 83 & -0.45 & 0.0001 & -0.07 & 0.4914 & 0.0000 & 0.0000 \\
\hline & Saline & 93 & -0.55 & 0.0002 & 0.06 & 0.6573 & 0.0001 & 0.0003 \\
\hline & Porto Scuso & 96 & -0.24 & 0.0350 & 0.26 & 0.0144 & 0.0088 & 0.0176 \\
\hline & Isola Piana & 96 & -0.32 & 0.0013 & 0.14 & 0.1298 & 0.0008 & 0.0024 \\
\hline
\end{tabular}




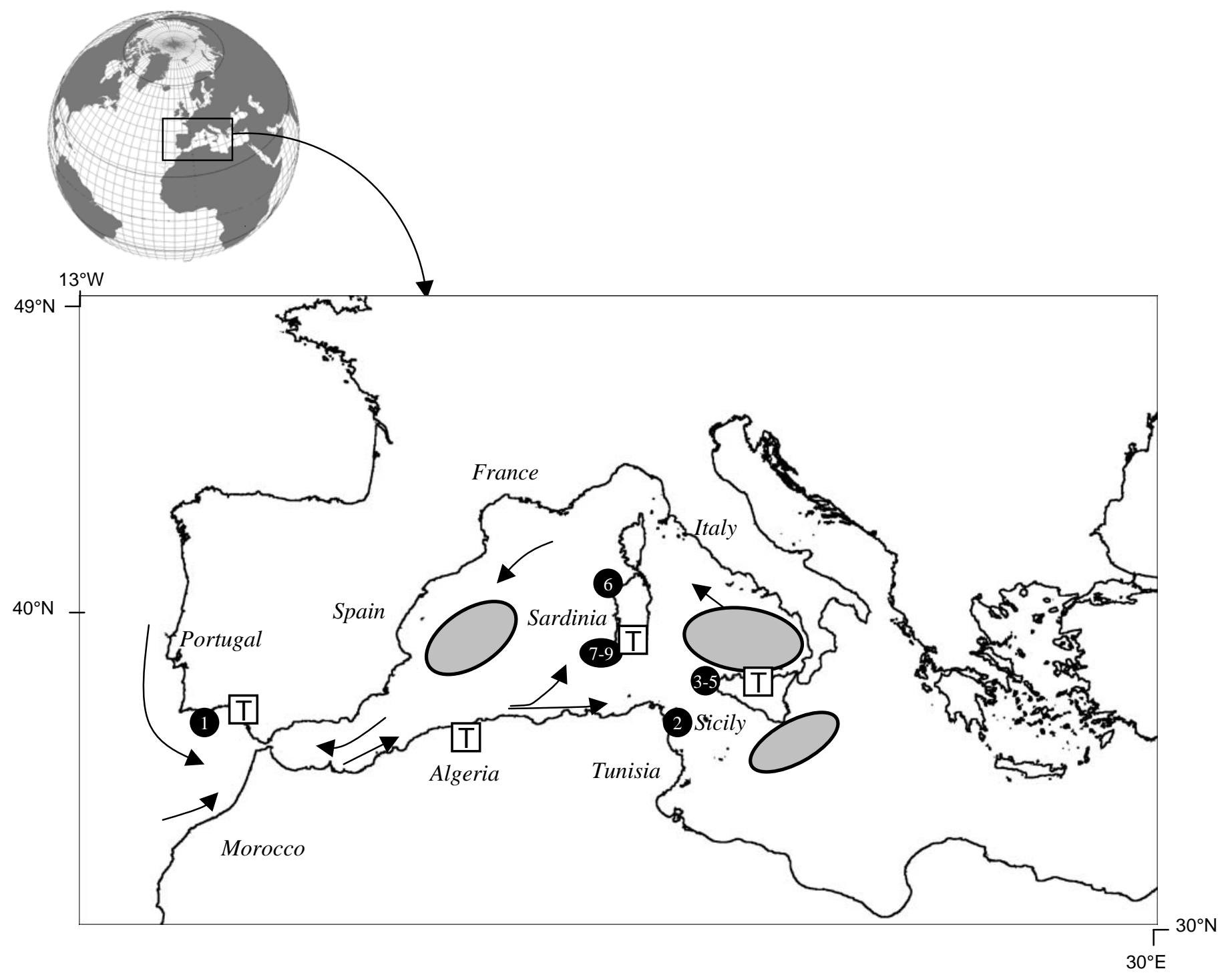

Figure 1 

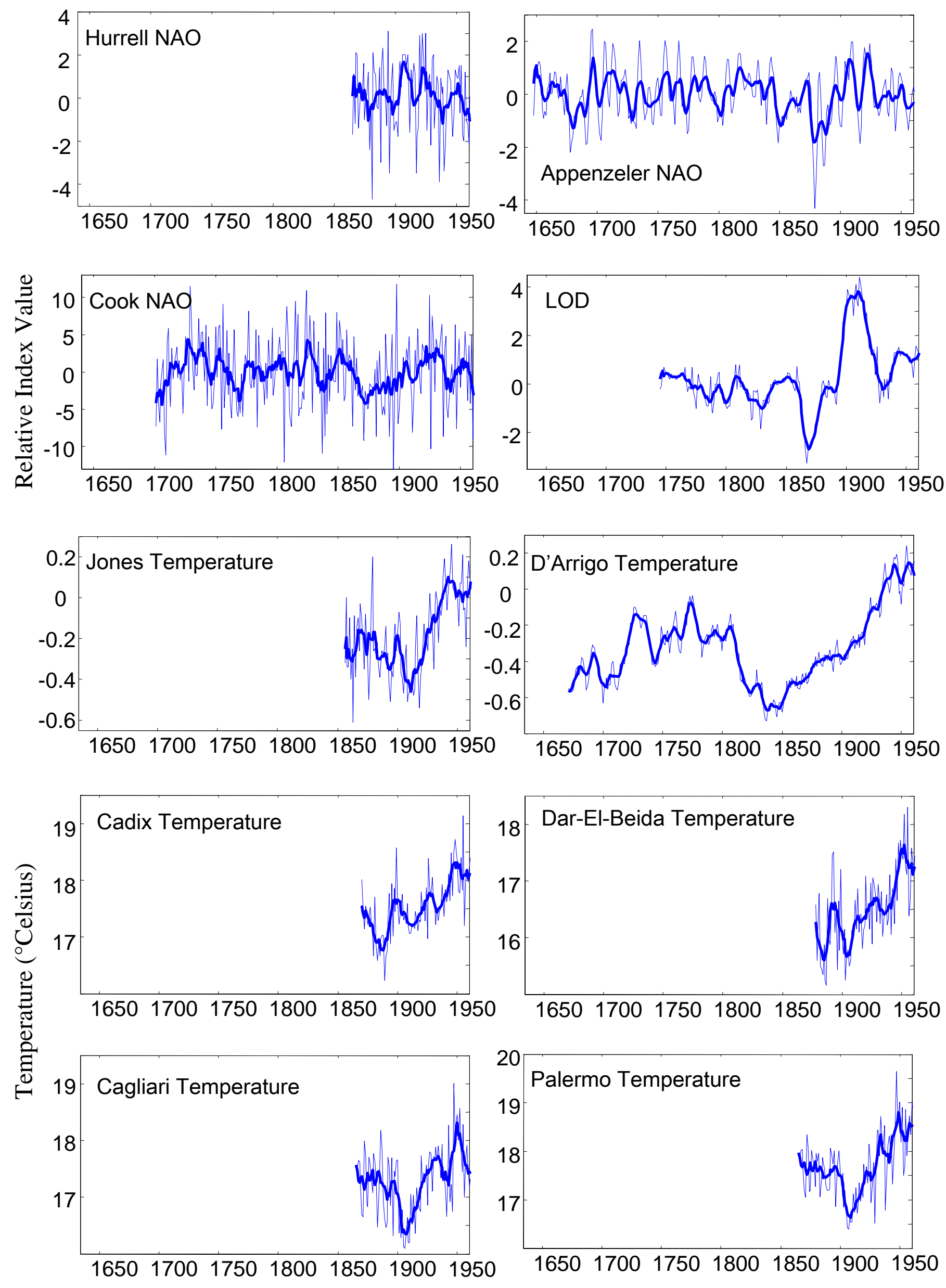

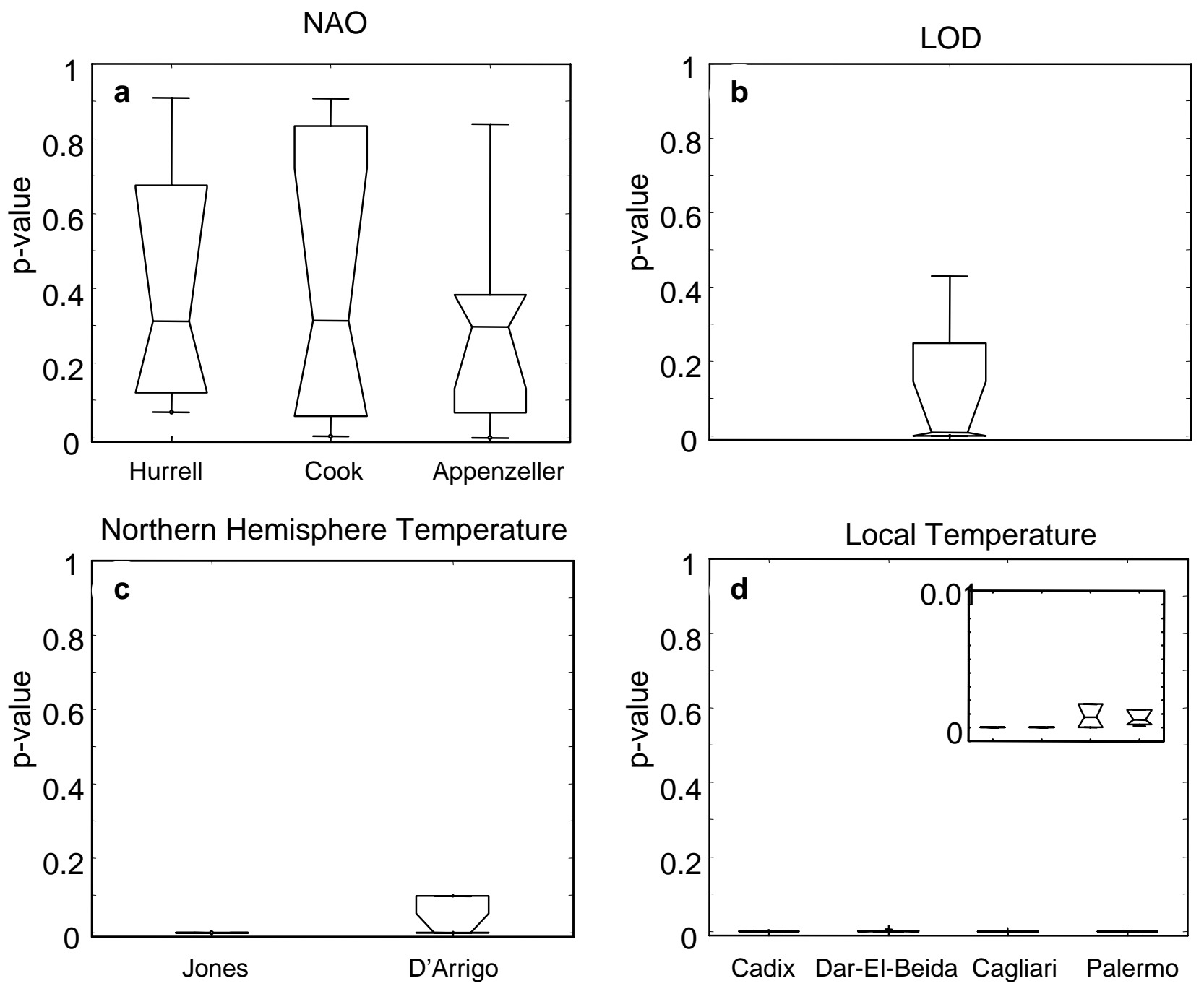

Figure 5 
Different Periods

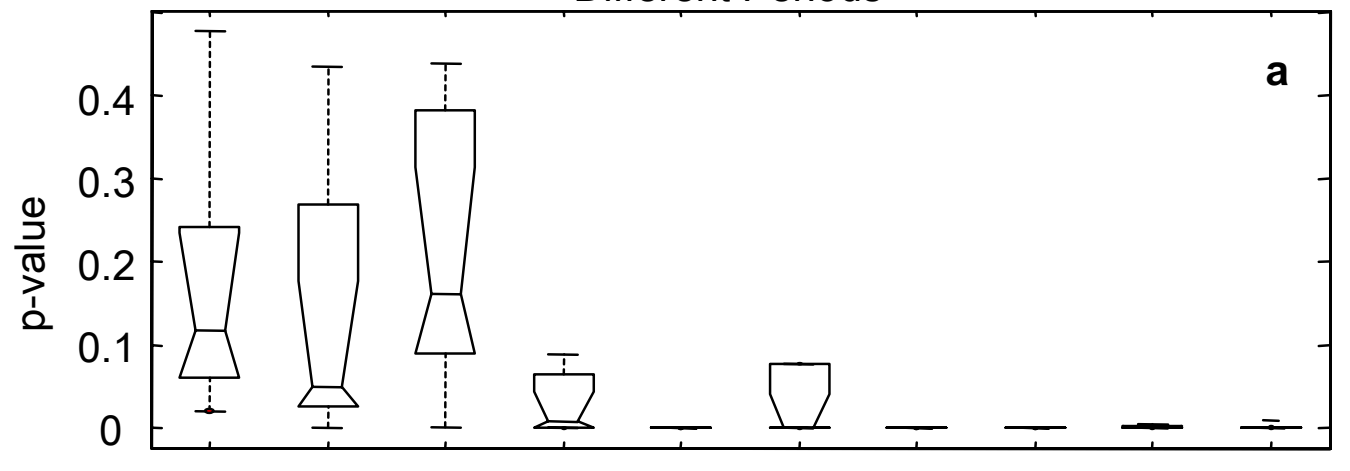

Common Period

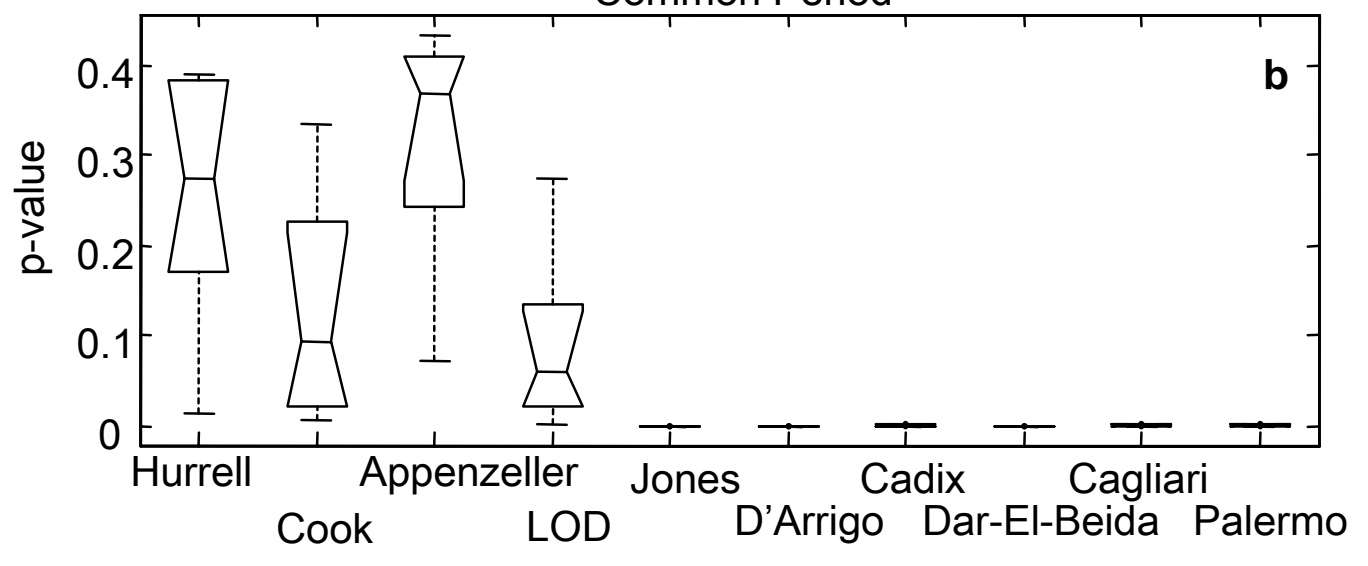

Figure 6 